\title{
The opinion of Master's degree graduates in Public Health, Warsaw Medical University on their career path plans
}

\author{
Corresponding author: \\ Ilona Cieślak, Department \\ of Education and Research in Health \\ Sciences, Faculty of Health Science, \\ Medical University of Warsaw, Poland, \\ e-mail: ilona.cieslak@wum.edu.pl
}

Medical Research Journal 2020; Volume 5, Number 4, 225-230 DOI: 10.5603/MRJ.a2020.0038 Copyright (C) 2020 Via Medica ISSN 2451-2591

\begin{abstract}
Introduction. Although statistical data demonstrate a systematic decrease in the interest in Public Health among student applicants, growth in the importance of public health professionals in the health system is increasingly recognised. Master's degree graduates in Public Health, Warsaw Medical University have a broad spectrum of possibilities when choosing their career path. The present study aimed to analyse plans for further education and career path among Master's degree graduates from the Public Health Division, Faculty of Health Sciences, Warsaw Medical University.

Materials and methods. The study involved 86 graduates (women constituted $83 \%$ of all) from the second-cycle degree programme in Public Health at the Public Health Division, Faculty of Health Sciences, Warsaw Medical University. The study enrolled second-cycle degree students who graduated in the academic year 2015-2016. Mean age of the study population amounted to 26.88 years (min. 24; max. 52; SD 4.540). The study used a questionnaire developed by the authors at the Department of Teaching and Education Outcomes, Faculty of Health Sciences, Warsaw Medical University, based on the list of educational outcomes adopted by the resolution of Warsaw Medical University Senate. Students filled in the questionnaire after graduation while receiving the certificate evidencing completion of the programme in the Dean's Office

Results. Most respondents graduated from the second-cycle degree programme in Public Health ( $n=67.78 \%$ ) specialising in Management $(n=49.57 \%$ ). Over $80 \%$ of graduates did not intend to commence a third-cycle degree programme (doctoral course). Most study participants worked during their studies ( $n=61.71 \%$ ) and their job was related to the area of public health $(n=37.43 \%$ ). Graduates saw themselves in a job that is consistent with their major $(n=60.70 \%)$, in public sector $(n=33.38 \%)$ and in managerial positions ( $n=23,27 \%$ ).

Conclusions.

1. There is a need to show students as early as during their educational cycle a wide range of employment options they have after graduation, for instance by recommending summer internship places.

2. A summer internship database for students should be developed at Warsaw Medical University in order to help Public Health students enter the health system.

Key words: public health, public health graduates, career choice, education standards, work
\end{abstract}

Med Res J 2020; 5 (4): 225-230

\section{Introduction}

A degree programme in Public Health is offered by a number o public and private university-level schools in Poland [1]. Although statistical data demonstrate a systematic decrease in the interest in Public Health among student applicants, growth in the importance of public health professionals in the health system is increasingly recognised $[2,3]$. During the course of study, students attend lectures, seminars and classes on different areas of knowledge divided into general and major-related educational content. In the academic year 2015-2016, basic courses at Warsaw Medical University included, among others: Economics, Biostatistics, 
Research Methodology, Sociology, Psychology, Capital Market, Public Finance, Media Communication, and Environmental Protection. Major-related courses included, among others, the following: Epidemiology, Social and Health Policy, Sanitary and Epidemiological Surveillance, Social and Health Insurance, Health Needs Assessment and Forecasting, International Health Issues, Contracting and Financing of Medical Services, Pharmacoeconomics, Law in Healthcare, and Quality Management in Healthcare [4]. Owing to such a choice of content, Public Health is an interdisciplinary major that offers a wide range of possible career paths. In addition to in-class training, students are obliged to do summer internships after the first year of the second-cycle programme amounting to 160 teaching hours [5].

Master's degree graduates in Public Health, Warsaw Medical University have a broad spectrum of possibilities when choosing their career path. A resolution of Senate of September 24, 2012, on educational outcomes set for programmes offered at Warsaw Medical University specifies possible employment opportunities for graduates in the field of Public Health. They include, among others, healthcare institutions (central and local levels of government, social, and private), health insurance institutions, non-governmental organisations, sanitary surveillance, environmental organisations, and $\mathrm{EU}$ and international bodies (with foreign language proficiency) [6].

Evaluation of graduates' career path plans, as well as, their satisfaction with and expectation regarding the major may prompt a change in the curriculum. This could make the programme in Public Health more attractive to prospective students and better tailored to labour market needs.

\section{Aim of the study}

The present study aimed to analyse plans for further education and career path among Master's degree graduates from the Public Health Division, Faculty of Health Sciences, Warsaw Medical University.

\section{Material and methods}

\section{Material}

The study involved 86 graduates (women constituted $83 \%$ of all) from the second-cycle degree programme in Public Health at the Public Health Division, Faculty of Health Sciences, Warsaw Medical University. The study enrolled second-cycle degree students who graduated in the academic year 2015-2016 (the entire course of study between 2014-2016.) Mean age of the study population amounted to 26.88 years (min. 24; max. 52; SD 4.540). Unmarried persons constituted the vast majority of the study participants (84\%, 72 persons), followed by married ones (15\%, 13 persons). One person was divorced.

\section{Methods}

A voluntary questionnaire study was conducted between July and September 2016. Students filled in the questionnaire after graduation while receiving the certificate evidencing completion of the programme in the Dean's Office, in a dedicated site, in order to preserve anonymity. The time required for filling the questionnaire was about 15 minutes.

An original questionnaire used in the study was developed in the Division of Teaching and Outcomes of Education, Faculty of Health Sciences, Warsaw Medical University based on the list of educational outcomes established by the resolution of Warsaw Medical University Senate and existing curricula in the Division of Public Health, Faculty of Health Sciences, Warsaw Medical University.

There were three parts of the questionnaire. The first part aimed to find out what students think about the level of achievement of particular educational outcomes during the first-cycle degree programme in Public Health. The second part of the questionnaire concerned the self-assessment of students with respect to particular educational outcomes for the first-cycle degree programme in Public Health.

The first two parts of the questionnaire comprised a total of 72 statements divided into three domains: knowledge (29 statements), skills (30 statements), and social competence (13 statements). Students rated the level of achievement of educational outcomes and their self-assessment on a five-point Likert scale, with 1 referring to "Strongly disagree" and 5 to "Strongly agree." In addition, educational outcomes in the areas of knowledge and skills were divided into the following fields, considered as most important for public health: Public Health (ZP), Legal Sciences (P), Economic Sciences (E), and other fields of knowledge (I). Given the aim of the present study, the first and second parts of the questionnaire were not included in the present article and will be discussed elsewhere.

The third part of the questionnaire comprised 19 close-ended and semi-open-ended, single and multiple-choice questions regarding the issue of continuing higher education and career path plans after graduation from the Division of Public Health, Faculty of Health Sciences, Warsaw Medical University.

\section{Results}

Most respondents graduated from the second-cycle degree programme in Public Health ( $n=67.78 \%$ ) 
specialising in Management $(n=49.57 \%)$. Over $80 \%$ of graduates did not intend to commence a third-cycle degree programme (doctoral course). One-third of the study population would rather decide to study the same major if they could choose again.

Respondents were asked about their attitude towards the summer internships they had done after the first year of the second-cycle degree programme. Most of the students had their internships in healthcare entities such as hospitals or public health care centres ( $n=63.73 \%$ ). The graduates considered their internships as rather valuable $(n=36.42 \%)$ and helpful in achieving educational outcomes set in the curriculum for the second-cycle degree programme in Public Health $(n=31.36 \%)$.

Most study participants worked during their studies ( $n=61.71 \%$ ) and their jobs were related to the area of public health $(n=37.43 \%)$. Graduates saw themselves in a job that is consistent with their major ( $n=60.70 \%$ ), in public sector $(n=33.38 \%)$ and in managerial positions ( $n=23,27 \%)$.

Respondents expected a salary between 2,501 and 3,000 PLN $(n=38.44 \%)$ in their future job.

See Table 1 for a detailed distribution of answers to the questions from the questionnaire.

\section{Discussion}

The present study constitutes the first attempt to assess career path plans of graduates from the second-cycle degree programme in Public Health at Warsaw Medical University.

The present results demonstrated a positive image of a graduate, i.e. a public health professional who is satisfied with his/her choice of major, does not intend to migrate to other countries and is willing to find employment in the area of public health after graduation.

Women represented the vast majority of all study participants (83\%), which coincides with a general trend towards feminisation of medical universities in Poland and overrepresentation of women employed in the broad area of healthcare [7, 8]. This seems to be beneficial for this particular field as it often requires socialisation and cooperation between a number of entities and women are considered to be better at these fields [9].

In the $21^{\text {st }}$ century, Master's degree has become quite common and the number of people willing to commence a third-cycle degree programme (doctoral course) is growing [10]. However, as little as $16 \%$ of the study participants considered further education. This may be a result of a number of factors, including interests and economic or family situation. Numerous studies show a similar trend: the number of healthcare graduates aiming for a professional research career is decreasing [11-12].

A positive aspect of the present study is that graduates, those already working during the course of study as well as those who will start looking for employment, were willing to work in the filed related to public health. This demonstrates that the choice of major was both thoughtful and intentional and the respondents had background knowledge related to the field of studies [9]. The fact that graduates stay in the healthcare system after graduation benefits not only themselves but also the state which invests in educating young adults.

A slight majority of study participants indicated the public sector as the one they were going to seek employment in (38\%). Similar results were obtained by researchers of the Medical University of Gdańsk who studied the opinions of students on their future employment [12]. However, a study by Cianciara revealed that most students of private university-level schools were going to look for a job in the private sector [9]. This kind of distribution of answers may be influenced by the type of school students attend as well as their economic prospects.

A summer professional internship is a compulsory part of the education programme in Public Health that offers students an opportunity to use their theoretical knowledge in practice. Properly selected and carried out internships offer students an opportunity to verify skills acquired during the course of study against real expectations of potential employers.

Students of Public Health at the Faculty of Health Science, Warsaw Medical University are obliged to do summer internships after the first year of the second-cycle programme [5]. Graduates emphasised the high value of their internships in relation to the achievement of educational outcomes specified for Public Health. This demonstrated the importance of internships to the development of skills and competence acquired only in theory by the respondents during the course of study. Despite many possible places where Public Health students may do their internships, most study participants had chosen healthcare entities (73\%). It seems advisable to develop an internship database based on students' experience and in agreement with entities taking on interns that would integrate the university staff and representatives of entities offering internships and, prospectively, potential workplaces of Public Health graduates.

Interestingly, graduates who had already worked while studying were usually engaged in health promotion. Most graduates, however, see themselves in managerial positions. This may be indicative of a lower self-assessment of skills among students who had already worked while studying or less restrictive requirements of employers. 
Table 1. Distribution of answers to the questions from the questionnaire

\begin{tabular}{|c|c|c|c|}
\hline Question & Answer & $\begin{array}{c}n \\
\text { (number of } \\
\text { respondents) }\end{array}$ & [\%] \\
\hline \multirow{3}{*}{$\begin{array}{l}\text { Which of the following specialisations } \\
\text { at the second-cycle degree programme } \\
\text { in Public Health, WMU have you } \\
\text { graduated from? }\end{array}$} & Heatlh Promotion and Epidemiology & 36 & 42 \\
\hline & Management & 49 & 57 \\
\hline & No answer & 1 & 1 \\
\hline \multirow[t]{3}{*}{ I graduated from } & a full-time degree programme & 67 & 78 \\
\hline & a part-time degree programme & 19 & 22 \\
\hline & No answer & 0 & 0 \\
\hline \multirow{3}{*}{$\begin{array}{l}\text { Do you intend to enrol in a third-cycle } \\
\text { degree programme (doctoral course)? }\end{array}$} & Yes & 14 & 16 \\
\hline & No & 72 & 84 \\
\hline & No answer & 0 & 0 \\
\hline \multirow{3}{*}{$\begin{array}{l}\text { Where do you intend to enrol in the } \\
\text { third-cycle degree programme? }\end{array}$} & Warsaw Medical University & 8 & 9 \\
\hline & Other & 6 & 7 \\
\hline & No answer & 72 & 84 \\
\hline \multirow{6}{*}{$\begin{array}{l}\text { Would you decide to study Public } \\
\text { Health if you could choose } \\
\text { the second-cycle degree programme } \\
\text { again? }\end{array}$} & Strongly not & 14 & 16 \\
\hline & Rather not & 17 & 20 \\
\hline & No opinion & 12 & 14 \\
\hline & Rather yes & 30 & 35 \\
\hline & Strongly yes & 13 & 15 \\
\hline & No answer & 0 & 0 \\
\hline \multirow{9}{*}{$\begin{array}{l}\text { Where did you have your summer } \\
\text { internship during the second-cycle } \\
\text { degree programme? }\end{array}$} & Ministry of Health & 8 & 9 \\
\hline & Polish National Health Fund & 4 & 5 \\
\hline & $\begin{array}{l}\text { Healthcare entity (hospital, Public Health Care Centres, } \\
\text { etc.) }\end{array}$ & 63 & 73 \\
\hline & Sanepid (State Sanitary Inspection) & 4 & 5 \\
\hline & Pharmaceutical company & 12 & 14 \\
\hline & Insurance company & 1 & 1 \\
\hline & $\begin{array}{l}\text { Abroad (e.g. European Parliament, European Commission, } \\
\text { non-governmental organisations, Health Ministries, etc.) }\end{array}$ & 0 & 0 \\
\hline & Other & 14 & 16 \\
\hline & No answer & 0 & 0 \\
\hline \multirow{6}{*}{$\begin{array}{l}\text { Do you perceive your summer } \\
\text { internship as valuable? }\end{array}$} & Strongly not & 7 & 8 \\
\hline & Rather not & 18 & 21 \\
\hline & No opinion & 7 & 8 \\
\hline & Rather yes & 36 & 42 \\
\hline & Strongly yes & 18 & 21 \\
\hline & No answer & 0 & 0 \\
\hline \multirow{6}{*}{$\begin{array}{l}\text { Do you believe that your internship } \\
\text { helped to achieve educational outcomes } \\
\text { set in the curriculum for the second-cycle } \\
\text { degree programme in Public Health? }\end{array}$} & Strongly not & 10 & 12 \\
\hline & Rather not & 23 & 27 \\
\hline & No opinion & 11 & 13 \\
\hline & Rather yes & 31 & 36 \\
\hline & Strongly yes & 11 & 13 \\
\hline & No answer & 0 & 0 \\
\hline \multirow{4}{*}{$\begin{array}{l}\text { Do you wish to migrate to other } \\
\text { countries after graduation from } \\
\text { the second-cycle degree programme } \\
\text { for better job opportunities? }\end{array}$} & Yes & 5 & 6 \\
\hline & No & 45 & 52 \\
\hline & I do not know & 36 & 42 \\
\hline & No answer & 0 & 0 \\
\hline
\end{tabular}


Table 1 cont. Distribution of answers to the questions from the questionnaire

\begin{tabular}{|c|c|c|c|}
\hline Question & Answer & $\begin{array}{c}n \\
\text { (number of } \\
\text { respondents) }\end{array}$ & [\%] \\
\hline \multirow{3}{*}{$\begin{array}{l}\text { Did you work while studying a Master's } \\
\text { degree? }\end{array}$} & Yes & 61 & 71 \\
\hline & No & 24 & 28 \\
\hline & No answer & 1 & 1 \\
\hline \multirow{3}{*}{$\begin{array}{l}\text { Was your work related to the area } \\
\text { of public health? }\end{array}$} & Yes & 37 & 43 \\
\hline & No & 26 & 30 \\
\hline & No answer & 23 & 27 \\
\hline \multirow{8}{*}{$\begin{array}{l}\text { Which area of public health did you } \\
\text { work in while studying } \\
\text { a Master's degree? }\end{array}$} & Epidemiology & 3 & 3 \\
\hline & Health Promotion & 13 & 15 \\
\hline & Health Policy & 1 & 1 \\
\hline & Management in healthcare & 11 & 13 \\
\hline & Pharmacoeconomics & 3 & 3 \\
\hline & Health Insurance & 2 & 2 \\
\hline & Other & 13 & 15 \\
\hline & No answer & 40 & 47 \\
\hline \multirow{4}{*}{$\begin{array}{l}\text { Are you going to stay in this job after } \\
\text { graduation with a Master's degree? }\end{array}$} & Yes & 28 & 33 \\
\hline & No & 24 & 28 \\
\hline & I do not know & 10 & 12 \\
\hline & No answer & 24 & 28 \\
\hline \multirow{4}{*}{$\begin{array}{l}\text { Are you going to find employment } \\
\text { in public health after graduation } \\
\text { with a Master's degree? }\end{array}$} & Yes & 60 & 70 \\
\hline & No & 8 & 9 \\
\hline & I do not know & 16 & 19 \\
\hline & No answer & 2 & 2 \\
\hline \multirow{4}{*}{$\begin{array}{l}\text { What sector are you going to seek } \\
\text { employment after graduation with } \\
\text { a Master's degree? }\end{array}$} & Public & 33 & 38 \\
\hline & Private & 32 & 37 \\
\hline & I do not know & 10 & 12 \\
\hline & No answer & 11 & 13 \\
\hline \multirow{9}{*}{$\begin{array}{l}\text { Which area of public health } \\
\text { are you going to seek employment in? }\end{array}$} & Epidemiology & 8 & 9 \\
\hline & Health Promotion & 19 & 22 \\
\hline & Health Policy & 11 & 13 \\
\hline & Management in healthcare & 23 & 27 \\
\hline & Pharmacoeconomics & 5 & 6 \\
\hline & Health Insurance & 1 & 1 \\
\hline & Other & 8 & 9 \\
\hline & I do not know & 11 & 13 \\
\hline & No answer & 8 & 9 \\
\hline \multirow{8}{*}{$\begin{array}{l}\text { What net monthly income do you expect } \\
\text { to earn after graduation with a Master's } \\
\text { degree? }\end{array}$} & up to 1,500 PLN & 2 & 2 \\
\hline & 1,501-2,500 PLN & 14 & 16 \\
\hline & $2,501-3,500$ PLN & 38 & 44 \\
\hline & $3,501-4,500$ PLN & 20 & 23 \\
\hline & $4,501-5,000$ PLN & 5 & 6 \\
\hline & $5,001-10,000$ PLN & 5 & 6 \\
\hline & more than 10,000 PLN & 1 & 1 \\
\hline & No answer & 1 & 1 \\
\hline
\end{tabular}

Source: Author's own elaboration 
Respondents expected a net salary between 2,501 and 3,000 PLN after graduation, which is less than the average net income estimated by the Central Statistical Office for the healthcare sector in 2016 that exceeds 4000 PLN [13]. By providing this particular salary range students showed either their ignorance of the labour market or a lack of self-confidence and low self-esteem [12].

\section{Conclusions}

1. There is a need to show students as early as during their educational cycle a wide range of employment options they have after graduation, for instance by recommending summer internship places.

2. A summer internship database for students should be developed at Warsaw Medical University in order to help Public Health students enter the health system.

\section{Acknowledgements: None}

Statement of competing interests: None

\section{References}

1. Lewtak K, Piotrowicz M, Gajewska M, Urban E, Cianciara D. Wstepne wyniki badania "Moja praca w zdrowiu publicznym”. In: Cianciara D. ed. ie ma zdrowia bez badań w dziedzinie zdrowia publicznego. Narodowy Instytut Zdrowia Publicznego - Państwowy Zakład Higieny, Warszawa 2014

2. ulchinsky T, McKee M. Editorial: Education for a Public Health Workforce in Europe and Globally. Public Health Reviews. 2011; 33(1): 7-15, doi: 10.1007/bf03391617.

3. Paccaud F, Weihofen A, Nocera S. Public Health Education in Europe: Old and New Challenges. Public Health Reviews. 2011; 33(1): 66-86 doi: 10.1007/bf03391621.

4. Sylabus kierunku Zdrowie publiczne, Wydział Nauki o Zdrowiu, Warszawski Uniwersytet Medyczny [World Wide Web]; wnoz; c2017. http:// wnoz.wum.edu.pl (12.09.2020)

5. Praktyki dla kierunku Zdrowie publiczne, Wydział Nauki o Zdrowiu Warszawski Uniwersytet Medyczny [World Wide Web]; wnoz; c2017. http://wnoz.wum.edu.pl (12.09.2020).

6. Uchwała nr 77/2012 Senatu Warszawskiego Uniwersytetu Medycznego z dn. 24 września 2012 r. w sprawie określenia efektów kształcenia dla kierunków studiów prowadzonych w Warszawskim Uniwersytecie Medycznym [World Wide Web]; wum; c2017. http://dokumenty.wum. edu.pl/?rodzaj=1 (12.09.2020).

7. Główny Urząd Statystyczny. Szkoły wyższe i ich finanse w 2016 roku. http://stat.gov.pl/download/gfx/portalinformacyjny/pl/defaultaktualnosci/5488/2/13/1/szkoly_wyzsze_i_ich_finanse_w_2016_r..pdf (12.09.2020).
8. Główny Urząd Statystyczny. Pracujacy w gospodarce narodowej w 2016 roku. http://stat.gov.pl/download/gfx/portalinformacyjny/pl/defaultaktualnosci/5474/7/13/1/pracujacy_w_gospodarce_narodowew 2016 roku.pdf (12.09.2020)

9. Cianciara D, Piotrowicz M, Gajewska M. Zasoby kadrowe zdrowia publicznego i promocji zdrowia w Polsce. Cz. 3. Plany zawodowe studentów kierunku „zdrowie publiczne”. Probl Hig Epidemiol. 2010; 91(3): 482-488

10. Najwyższa Izba Kontroli. NIK o kształceniu na studiach doktoranckich. https://www.nik.gov.pl/plik/id,9897,vp,12191.pdf (12.09.2020).

11. Uniwersytet Jagielloński Collegium Medicum. Losy zawodowe absolwentów Wydziału Nauk o Zdrowiu UJ CM, rocznik 2009/2010. Raport_losow_zawodowych_absolwentow_WNoZ_UJCM.doc (12.09.2020).

12. Andrzejczyk A, Tyrańska-Fobke A. Nie tylko studia-postawy studentów zdrowia publicznego wobec przyszłego zatrudnienia. Piel Zdr Publ. 2013: 3(4): 337-344.

13. Główny Urząd Sttystyczny. Struktura Wynagrodzeń według zawodów w październiku 2016 [World Wide Web]. gus; c2017. http://stat.gov. $\mathrm{pl} /(20.09 .2020)$

14. Lewtak K, Piotrowicz M, Gajewska M, Urban E, Cianciara D. Wstępne wyniki badania „Moja praca w zdrowiu publicznym”. In: Cianciara D. ed. ie ma zdrowia bez badań w dziedzinie zdrowia publicznego. Narodowy Instytut Zdrowia Publicznego - Państwowy Zakład Higieny, Warszawa 2014

15. ulchinsky T, McKee M. Editorial: Education for a Public Health Workforce in Europe and Globally. Public Health Reviews. 2011; 33(1): 7-15, doi: 10.1007/bf03391617.

16. Paccaud F, Weihofen A, Nocera S. Public Health Education in Europe: Old and New Challenges. Public Health Reviews. 2011; 33(1): 66-86, doi: 10.1007/bf03391621.

17. Sylabus kierunku Zdrowie publiczne, Wydział Nauki o Zdrowiu, Warszawski Uniwersytet Medyczny [World Wide Web]; wnoz; c2017. http:// wnoz.wum.edu.pl (12.09.2020)

18. Praktyki dla kierunku Zdrowie publiczne, Wydział Nauki o Zdrowiu, Warszawski Uniwersytet Medyczny [World Wide Web]; wnoz; c2017. http://wnoz.wum.edu.pl (12.09.2020).

19. Uchwała $n r 77 / 2012$ Senatu Warszawskiego Uniwersytetu Medycznego z dn. 24 września 2012 r. w sprawie określenia efektów kształcenia dla kierunków studiów prowadzonych w Warszawskim Uniwersytecie Medycznym [World Wide Web]; wum; c2017. http://dokumenty.wum. edu.pl/?rodzaj=1 (12.09.2020)

20. Główny Urząd Statystyczny. Szkoły wyższe i ich finanse w 2016 roku. http://stat.gov.pl/download/gfx/portalinformacyjny/pl/defaultaktualnosci/5488/2/13/1/szkoly_wyzsze_i_ich_finanse_w_2016_r..pdf (12.09.2020)

21. Główny Urząd Statystyczny. Pracujacy w gospodarce narodowej w 2016 roku. http://stat.gov.pl/download/gfx/portalinformacyjny/pl/defaultaktualnosci/5474/7/13/1/pracujacy_w_gospodarce_narodowej_w_2016_roku.pdf (12.09.2020).

22. Cianciara D, Piotrowicz M, Gajewska M. Zasoby kadrowe zdrowia publicznego i promocji zdrowia w Polsce. Cz. 3. Plany zawodowe studentów kierunku „zdrowie publiczne”. Probl Hig Epidemiol. 2010; 91(3): 482-488

23. Najwyższa Izba Kontroli. NIK o kształceniu na studiach doktoranckich. https://www.nik.gov.pl/plik/id,9897,vp,12191.pdf (12.09.2020).

24. Uniwersytet Jagielloński Collegium Medicum. Losy zawodowe absolwentów Wydziału Nauk o Zdrowiu UJ CM, rocznik 2009/2010. Raport losow_zawodowych absolwentow WNoZ_UJCM.doc (12.09.2020).

25. AndrzejczykA, Tyrańska-Fobke A. Nie tylko studia-postawy studentów zdrowia publicznego wobec przyszłego zatrudnienia. Piel Zdr Publ. 2013; 3(4): 337-344

26. Główny Urząd Sttystyczny. Struktura Wynagrodzeń według zawodów w październiku 2016 [World Wide Web]. gus; c2017. http://stat.gov. $\mathrm{pl} /(20.09 .2020)$ 